Journal of Contemporary Educational Research

Research Article

\title{
Mind Mapping and Teaching Strategies of English language in High School under the Guidance of Key Competence
}

Yujuan Zhao

Class of 2011, Logistics management, Qiqihar University; High school English teacher of New Oriental; Executive director of Tianjin Runyu Jiaqi Education Consulting Co., Ltd.; Tianjin 300200, China

\begin{abstract}
Under the key competence, high school English teachers shall strengthen the use of mind mappings when developing reading and teaching activities, thus making English reading, and teaching more intuitive and logical. In this way, high school students can be more interested in English, and more active and autonomous in improving their English reading ability. This article explores and analyzes the problems existing in high school English reading teaching at current stage, and puts forward an effective strategy for using mind mappings to develop high school English reading and teaching under the key competence, with the hope of facilitating the development of English reading and teaching in high school.
\end{abstract}

Keywords: Key competence; Mind map; High school English; Reading teaching

Publication date: September, 2020

Publication online: 30 September, 2020

*Corresponding author: Yujuan Zhao, 779160701@ qq.com

Based on the current development of high school English reading and teaching, there are still some problems need to be solved. These problems have hindered the improvement of high school students' reading ability vastly. Therefore, high school English teachers should innovate English reading and teaching strategies under the guidance of key competence actively, by using mind mappings to reduce the difficulty of English reading besides helping high school students to learn English more easily.

\section{Problems in English reading and teaching in high schools}

\subsection{Relatively boring teaching methods, and poor} English reading literacy among the teachers

When preparing lessons, some high school English teachers have downloaded the corresponding courseware directly from the network platform. Besides, they have used other teachers' teaching courseware with or without modifications. Although some high school English teachers who are very committed in the teaching has prepared the complete and informative courseware, they allow the repeated reading from the students during the teaching, without any explanation and interpretation of the teaching contents. This states that many teachers do not analyze the connotation of the text comprehensively in the process of preparing lessons. The main reason of this problem is that teachers have been long-adopted the teaching model based on textbooks, gradually losing their sense of innovation, and forming ideological inertia. In addition, there are some teachers who had low English reading literacy. When carrying out reading and teaching, they pay too much attention to the explanation of English grammar and vocabulary, while neglecting the training of students' English reading literacy. When explaining English texts, they fail to do in-depth exploration and analysis, but only being superficial on the article by interpret the main idea and structure of the article briefly. In such a boring teaching model, there is challenges in improving the key competence of high school students.

1.2 Low interest in English of the high school 


\section{students}

The biggest source of motivation for people to do things is interest. If high school students are not interested or curious about English, they will not start reading on their own, nor they will comprehend the articles actively. The main reasons for high school students showing low interest in English are shown in Table 1.

\subsection{Excessive emphasis on students' results and neglection of teaching process}

Based on the current situation of English reading and teaching activities conducted by high school English teachers, some teachers have emphasized too much on the students' results and neglected the teaching process $^{[1]}$. The main reasons for this problem are shown in Table 2.

\section{Major advantages of using mind mappings}

\section{to develop high school English teaching under key competence}

With the continuous reformation of basic education curriculum, the requirements for high school English teaching have also been constantly improved. The indoctrination and cramming teaching models applied by teachers in the past when carrying out English teaching activities are obviously unable to meet the requirements of the new reformation of basic education curriculum $^{[2]}$. Therefore, requires high school English teachers are required to initiate innovative English teaching methods actively, with fully understanding the significance of reforming and improving English reading teaching under the key competence and the importance of mind mappings in English teaching. These advantages of mind mappings are shown in Table 3.

Table 1. The main reasons for high school students showing low interest in English

Reasons for high school students showing low interest in English

Explanation

Table 2. The main reasons for strong emphasis on student's results

Reasons for strong emphasis on student's results
1. In the English class, teachers usually stand on the podium and give a detailed explanation of English knowledge.

2. Junior high school students are in passive learning. They are inactive in thinking and are unwilling to actively think and explore English-related knowledge.

1. The English vocabularies among high school students are limited.

2. When faced with longer sentences or compound sentences, students are usually clueless when facing longer or complex sentences.

3. Students have inadequate understanding of English grammar, and hard from them to intrepret the meaning of new words through context.

1. Students usually being refusing and having difficulty in reading the English text when encountering a lot of new vocabularies or longer English texts.

2. In English classes, little students are being responsive to teachers' questions. They are increasingly lacking in self-confidence in learning, thus causing them in lacking strong interest in English.
Teaching philosophy is outdated

Pressured by the enrollment rate
Explanation

As new round of basic education curriculum reformation has been implemented, some teachers still have not changed their teaching concepts in time and are still using the test-oriented education concepts.

Many high school schools attach great importance to the enrollment rate, and many parents also consider it as the only criterion for considering the quality of a high school. Due to the pressure of the enrollment rate, high school English teachers have to be utilitarian when conducting teaching. Therefore, they only teach students the skills of solving problems in English and ignore the in-depth interpretation of English texts. 
Table 3. The advantages of mind mapping in high school English teaching

Explanation

Contribute to the understanding of 1. Mind mappings can clearly show the structure and creative ideas of English context.

English among high school students

2. Mind mappings aggregate new English vocabularies together thus students can study and memorize uniformly besides understanding the context more accurately and efficiently.

Help stimulating high school students' 1. Break through the traditional teacher-led teaching model.

interest in learning

2. High school students become the main body of teaching activities.

3. High school students are required to participate effectively.

Help developing good reading habits among high school students.

Under the subtle guidance of teachers, students will consciously draw mind maps to help them understand and analyze when reading a longer article and they will naturally develop a good English reading habit.

3 Effective strategies for using mind mapping in high school English teaching under key competence

\subsection{Strengthen high school students' awareness of using mind mappings}

The reformation of basic education curriculum clearly pointed out that under the key competence, high school English teachers shall fully reflect the dominant position of high school students in the process of using mind mappings to carry out English teaching activities as the students are the knowledge gainers builders of knowledge but not the English teachers. The participation of high school students in English teaching directly affects the quality and effectiveness of teaching. Judging from the current high school English teaching, most of the reading materials are long, and the content involved is also relatively diversified, including both aesthetic contents and scientific contents. After the implementation of the new round of basic education curriculum reformation, the content of high school English teaching is more interesting and informative, which has a very good inspiration for the thinking of high school students. Enhancing the awareness of using mind mappings for high school students can acquire important application values of mind mappings in high school English teaching ${ }^{[3]}$. Therefore, high school English teachers should be more careful in designing teaching methods. The teaching contents should be highly targeted, not only to inspire the high school students, but also to encourage students participating in discussion actively. Besides, mind mappings can effectively stimulate students' interest in English reading and develop good habit of using mind mappings in English among students ${ }^{[4]}$. For example, when a high school English teacher teaches the lesson "Travelling around", he can use multimedia teaching equipment to play a video for students to introduce the world's famous tourist attractions. Then, the teacher can ask the question: Where would you like to travel the most? and encourage students to express in English. After that, the teacher can guide the students to draw a mind map about travel. In the process of drawing mind maps, students will naturally have a deep knowledge and understanding of the content of the text.

\subsection{Mind mapping in high school English teaching}

The application of mind mappings in high school English teaching can present the content of the text to students more clearly and vividly, thus enhancing the learning experience of the students ${ }^{[5]}$. Mind mapping can gradually increase the difficulty of teaching, making a gradual transition from simple to difficult in English teaching, which is more helpful to stimulate high school students' interest in English ${ }^{[6]}$. For example, when a high school English teacher teaches the lesson Music, he can firstly guide the students to read the article quickly to filter out key words, and then ask the students to use Music as the central word and the filtered keywords as the backbone to draw the branches of the mind map, and finally form a complete mind map. When the students finish drawing the mind map, they naturally clarify the thinking of reading ${ }^{[7]}$.

\subsection{Pay attention to the evaluation of mind mappings}

Teaching evaluation is an indispensable and important link when high school teachers using mind mappings to conduct English teaching ${ }^{[8]}$. To maximize the 
advantage of mind mappings, teachers should conduct a comprehensive evaluation of teaching ${ }^{[9]}$. For example, when teaching a lesson about Wildlife Protection, after the students completing the mind map drawing, the teacher can encourage the students to self-evaluate their own mind map and describe their own thinking path after completing the mind map drawings. This is not only encourage high school students to better understand the advantages of mind mapping, but also further deepen their understanding and memory of this article. Then, the teacher can guide the students to evaluate the mind maps of each other. In this process, the effect of learning from each other can be achieved. Finally, teachers should make an objective evaluation of the mind maps of the students. What needs special attention is that motivation should be prioritized to avoid discouragement of students' self-confidence in improving English when evaluating the mind map of the students ${ }^{[10]}$

\section{Conclusion}

To sum up, in the process of conducting English teaching activities, high school English teachers must recognize some of the shortcomings in their own teaching, but also the importance of using mind mappings to carry out teaching activities. Teachers should strengthen students' awareness of using mind mapping for English, and carefully design teaching content to encourage them to gradually develop good reading habits, therefore laying a good foundation for students' future learning and boosting the English knowledge.

\section{References}

[1] Huang QF. High school English reading teaching strategies from the perspective of subject core literacy[J]. Quality Education in West China, 2020, 6(10): 67-69.

[2] Fan MC. A case study of English reading teaching in senior high schools based on mind maps [D]. Tianjin Normal University, 2020.

[3] Xue L. An experimental study of mind mapping in improving the metacognitive strategies of high school students' English reading [D]. Hebei Normal University, 2020.

[4] Luo YJ. A brief introduction to the role of mind maps in promoting high school students' English reading comprehension ability[J]. English Square, 2020(05): 124-125.

[5] Xia ZM. On the use of mind maps in high school English reading teaching based on schema theory[J]. English Teachers, 2019, 19(21): 30-33+37.

[6] Zeng DH. The role of mind maps in the interpretation of high school English reading text under the guidance of core literacy[J]. Curriculum Education Research, 2019(48).

[7] Liu YJ. Talking about the strategy of using mind map to promote the improvement of core literacy_- Taking the People's Education Edition Module 8 Unit 5 A Visit to the Zhoukoudian Caves as an example [J]. Famous Teacher Online, 2019, 82(9): $17-18$.

[8] Lin B. The Wonderful World on the Map_A high school English reading class constructed with mind maps[J]. Campus English, 2019(27):119-121.

[9] He TL. The application of mind maps in high school English reading__ Taking the People's Education version of Senior One English Book4 Unit2 Chemical or Organic Farming? as an example[J]. Campus English, 2018(18).

[10] Su LX. Talking about how to cultivate students' core literacy in the teaching of English extended reading in high school---Taking the teaching of the fifth unit of compulsory 3 of the People's Education Edition as an example[J]. Gaokao, 2018(18). 